\section{EMBRYRIDDLE \\ Aeronautical University}

SCHOLARLY COMMONS
International Journal of Aviation, Aeronautics, and Aerospace

\title{
A Conceptual Framework for Valuating Airline Frequent Flyer Program Miles
}

Yi Gao

Purdue University, yigao@purdue.edu

Follow this and additional works at: https://commons.erau.edu/ijaaa

Part of the Management and Operations Commons, Marketing Commons, and the Tourism and Travel Commons

\section{Scholarly Commons Citation}

Gao, Y. (2020). A Conceptual Framework for Valuating Airline Frequent Flyer Program Miles. International Journal of Aviation, Aeronautics, and Aerospace, 7(1). https://doi.org/10.15394/ijaaa.2020.1447

This Article is brought to you for free and open access by the Journals at Scholarly Commons. It has been accepted for inclusion in International Journal of Aviation, Aeronautics, and Aerospace by an authorized administrator of Scholarly Commons. For more information, please contact commons@erau.edu. 
Frequent flyer programs were firstly created by the airline industry in the late 1970s - early 1980s (de Boer \& Gudmundsson, 2012; Rowell, 2010). Originally as a marketing tool, frequent flyer programs were designed to reward repetitive purchase of frequent travelers with the aim of enhancing customer loyalty. Four decades later, frequent flyer programs have evolved from merely an ancillary marketing tool into a primary revenue contributor for airlines. For instance, in the financial year of 2017-2018, Qantas Loyalty, the frequent flyer program entity of Qantas Airways (Australia), reported a total revenue of $\mathrm{A} \$ 1.55$ billion and underlying earnings before interest and taxes (EBIT) of A $\$ 372$ million, accounting for 23.2\% of the profit for the entire Qantas Group (Qantas, 2018). Today, the loyalty arm of airlines has successfully developed a diverse and broad collaboration network far beyond the traditional airline or even the tourism industry. Their partners now include banks, telecommunication companies, insurance companies, retailers, and many other businesses (United Airlines, 2019b).

In the value chain of frequent flyer programs, miles (also referred as points by some programs) are the core element. A mile is a basic unit measuring the engagement of travelers with the airline either in the form of traveling or spending. Miles serve as the medium for travelers to access benefits provided by the hosting airline (Crawford, 2013). Miles are issued either directly by airlines or indirectly through airline partners to frequent flyer program members, and are later recycled by airlines when members redeem them for awards (see Figure 1).

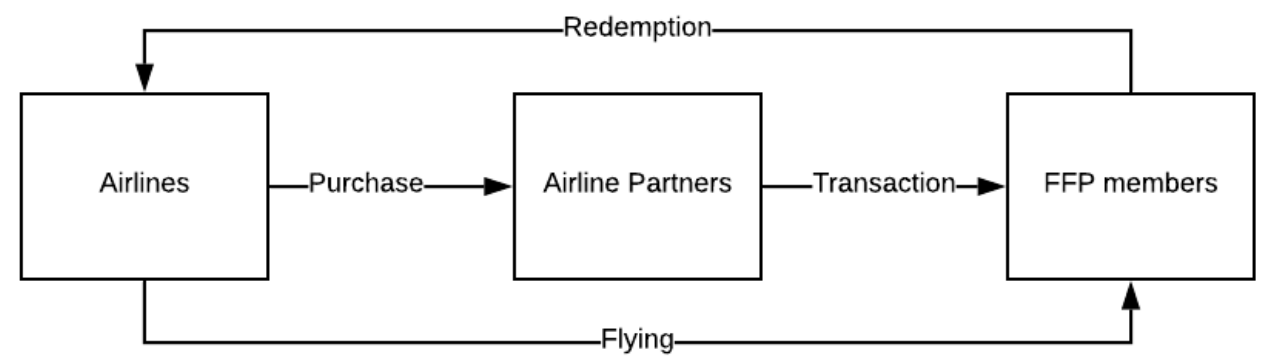

Figure1. The movement of miles in the FFP value chain.

Miles are increasingly recognized and treated as virtual currencies in the frequent flyer program world (Chan, Kemp, \& Finsterwalder, 2016). They can be used to redeem for flight tickets, cabin class upgrade, general merchandise, travel vouchers, etc. Savvy travelers view miles as assets stored in their frequent flyer accounts. Airline treat unredeemed outstanding miles as a form of liabilities on balance sheets. In a Canadian court case, miles are even treated as matrimonial property by a couple when filing for divorce (Crawford, 2013).

However, some researchers believe that frequent flyer program miles could only be viewed as near money or pseudo money at best. Per Liston-Heyes (2002), 
an ideal form of money must possess seven attributes, which are 1) acceptability, 2) convenience, 3) durability, 4) divisibility, 5) uniformity, 6) difficulty to reproduce, and 7) stability of value. As digital records stored in airlines' databases, miles are relatively easy to use, have no durability issue, could come in any denominations, and are not prone to forgery. But miles are only accepted by merchants that are partnering with airlines, and their values are less stable over a long term with major airlines updating redemption rates frequently. In addition, even the most affordable awards require at least hundreds of miles for redemption, making frequent flyer accounts only with low miles basically unusable. Most frequent flyer programs also have miles expiration policies, which isn't the case for any currency. Therefore, frequent flyer programs miles are only regarded as nearmoney instead of legal tender (Chan et al., 2016).

As a multi-billion-dollar business, the frequent flyer program sector is still in its pre-regulation era. For currencies such as U.S. Dollar (USD), governments are collecting and publishing Consumer Price Index (CPI) periodically to measure the change of purchasing power of money over time (Bureau of Labor Statistics, 2019c). CPI is one of the key measures to indicate economic performance and to guide macroeconomic policies. By comparison, there is no government agency or external watchdogs monitoring the purchasing power of airlines' frequent flyer program miles or the change of such purchasing power, leaving frequent flyer program members to estimate the value of their miles themselves.

Despite a lack of external regulations, there have been a number of studies trying to address the value of frequent flyer miles from different perspectives. Results of online search suggest that the valuation of miles is mostly done by bloggers who focus on travel or credit card promotions, such as The Points Guy (2019), One Mile at a Time (2019), and Creditcards.com (2018). Bloggers could be experts in their fields and their opinions are valuable to readers, yet there is little explanation on methodology of assessment provided in their articles. Airlines are interested in this topic, too. Basumallick, Ozdaryal, and Madamba-Brown (2013) of United Airlines use internal ticketing data to estimate the perceived value of United MileagePlus miles when redeeming for domestic, regional (Hawaii), and international award tickets. Their analysis only considers award tickets of their own flights, but fails to capture a much more diverse award options that are available to MileagePlus members. Similarly, Jalbert, Stewart, and Martin (2010) use cash price of flight tickets to calculate values of miles in their study on credit card benefits. Gao, Carrigg, Lewinski, Polderman and Tkalcevic (2018) assess the perceived value of frequent flyer program benefits in general among Australian travelers.

The valuation of frequent flyer program miles is a persistent topic with tax departments. It has been debated for decades if frequent miles earned through paid business travels should be taxed as a form of revenue and how should the value of miles be determined. In the US, the Internal Revenue Service (IRS) issued a 
Technical Advice Memorandum in the 90s to instruct companies to report frequent flyer miles as income of employees (Dennis-Escoffier, 1996). However, the strong criticism from businesses and the travel industry soon stopped IRS from enforcing this immature decision. While IRS is struggling with technical difficulties in valuing frequent flyer miles, the issue whether miles should be taxed or not is brought back by commercial banks. Citibank is reported to issue tax from 1099MISC to customers who have earned credit card rewards (Nevius, 2012). Such practice implies that miles, along with other credit card rewards, are reported as miscellaneous income by financial institutions. This is challenged by some furious customers on court as there lacks a fair valuation of reported miles.

The taxation sector has investigated the challenge of valuing frequent flyer miles and summarized four different possible approaches (Banoff \& Lipton, 2012, $2014,2015)$. The first method is to use the price that airlines sell directly to business partners or customers. However, this approach could be flawed as miles are not uniformly priced when members purchase different number of miles from airlines. The second method is to assess miles using the highest possible value. This is problematic due to the limited availability of high-value redemption options, and thus is unfair to members who cannot achieve these options. The third approach is one of the most commonly used methods, which is to compare award tickets with the cash price of the same itinerary. This method brings another interesting challenge to taxation as it delays the realization of miles' values to redemption instead of receipt of miles. Such a treatment contradicts how monetary income is reported for taxation purposes. The final method of valuing miles is to use the "midpoint" of miles' value, which is perhaps the most practical way of assessment even though it is still unfair to some travelers.

Members of loyalty programs are puzzled with values of their mile assets, too. In a consumer survey on the value of Air Miles, a popular retail loyalty program in the UK, survey participants are found to over-estimate values of their miles (Liston-Heyes, 2002). Subjective valuation of miles can be affected by the attitude of consumers towards the program (Keh \& Lee, 2006). When consumers are satisfied with the program, they tend to maintain a longer relationship with the program and save miles for more valuable award options. On the other hand, if consumers are dissatisfied with the program, they tend to use miles for more immediate but less valuable awards.

The lack of consistent and commonly recognized method for valuing miles is the primary motivation for this study. In addition, very few academic studies have systematically addressed the usage of frequent flyer program miles. This study is the groundbreaking work in building a consistent theoretical framework of miles valuation, to assess if frequent flyer miles are or are not an acceptable form of currency, and to assess the utility of miles from travelers' perspectives. The results of this study could be significant to airlines for assessing their deferred miles 
revenues more accurately, to corporate partners for negotiating price when purchasing miles from airlines, to investors for assessing the financial positions of airlines or frequent flyer programs spun off from airlines, to the taxation industry for developing a more acceptable scheme to tax miles and rewards, and to travelers who are interested in maximizing the utility of their miles assets.

\section{The Conceptual Model of Miles Valuation}

Frequent flyer miles could be seen digital records stored in airlines' databases. According to terms and conditions of Aeroplan (Aeroplan, 2019), the frequent flyer program of Air Canada, miles "have no monetary value whatsoever." However, as a payment medium, miles successfully link frequent flyer program members' flying or spending activities to awards (Crawford, 2013). From this perspective, frequent flyer program miles indeed carry purchasing power, at least for redeemable awards. This study will use the equivalent cash price of awards to measure such purchasing power.

\section{Categorization of Redeemable Awards}

To determine the redemption value, or purchasing power, of frequent flyer miles, a close look at the categories of awards that can be redeemed with miles is necessary. After decades of business development by frequent flyer programs, the applicability of miles has greatly expanded from flight awards only to a wide range of awards. Table 1 summarizes major award categories available to selected frequent flyer programs (American Airlines - AAdvantage, Qantas Airways Qantas Frequent Flyer, and United Airlines - MileagePlus).

Table 1

Categories of Redeemable Awards (American Airlines, 2019d; Qantas, 2019a; United Airlines, 2019e)

\begin{tabular}{llll}
\hline Flight & Travel & Shopping & Experience \\
\hline Flight awards & Hotel awards & Merchandise & Entertainment \\
Flight & Car awards & Gift cards & events \\
upgrades & Cruise awards & Inflight shopping & Exclusive \\
Miles plus pay & Vacation awards & Insurance & experiences \\
& $\begin{array}{l}\text { Lounge } \\
\text { membership }\end{array}$ & premiums & \\
& & & \\
\hline
\end{tabular}

Flight related awards are the primary award category that can be redeemed with frequent flyer program miles. Members use a required number of miles to exchange for tickets of flights operated either by the hosting airline or partner airlines. Miles can also be used to upgrade existing flight bookings from lower cabin classes to premium classes such as business class or first class for better 
traveling experiences. In recent years, an increasing number of airlines allow their members to pay for flight bookings with a mix of cash and miles. This option reduces the minimum miles threshold, and makes flight awards more accessible to a broader member base.

The airline industry and the tourism industry are naturally interconnected. Products of both industries are being distributed through same global distribution systems (GDS). Airlines allow miles redemption for travel awards such as hotel rooms, car rentals, cruise trips or vacations. Some airlines also allow their members to pay club/lounge membership fees using miles. Miles could be used to pay for general merchandise, which are normally sold by online retailers that are partnering with airlines. In order to enhance the emotional loyalty of their members, major loyalty programs provide opportunities for their members to buy or to bid for selected exclusive experiences, including sports or entertainment events. For instance, United Airlines held a serious of special events to celebrate the retirement of Boeing 747 from its fleet in 2018, after more than four decades of flying the jumbo jet. Access to these events were only available to MileagePlus members who won a special auction by placing the highest miles offer (Mutzabaugh, 2018). As such experience tickets are not always open to the public, some members value them highly and are willing to offer quite generously for such awards.

\section{Pricing of Awards}

By examining the redemption rates of different awards, two different pricing schemes could be identified. Some travel awards and most general merchandise awards use relatively fixed miles-to-cash conversion rates, which makes the valuation of miles straightforward. Using United Airlines' MileagePlus as an example, when miles are redeemed for hotel awards, United Airlines collaborate with Hotels.com. See Table 2 for the mile-to-cash rate for hotel bookings in Las Vegas made separately from MileagePlus' hotel searching page and Hotels.com.

Table 2

Value of United MileagePlus Miles for Hotel Bookings

\begin{tabular}{llll}
\hline Hotel & Cash Price & Miles Price & Rate (USD/mile) \\
\hline South Point Hotel & $\$ 69.00$ & 10,150 & $\$ 0.0068$ \\
Caesars Palace & $\$ 109.00$ & 16,030 & $\$ 0.0068$ \\
The Palms & $\$ 92.00$ & 13,530 & $\$ 0.0068$ \\
\hline
\end{tabular}

A more complicated pricing scheme is used for most airlines for flight and upgrade awards. Since the early days of frequent flyer programs, the number of miles required for an award flight is usually based on the distance of the trip or respective regions of origin and destination. See Table 3 for the U.S. domestic 
award chart of United Airlines' MileagePlus. Considering revenue tickets are dynamically priced, with price updated frequently due to the shift of supply and demand, the nominal conversion rate between miles and cash becomes variable instead of constant. In order to capture the variable rates used by region or distancebased flight awards or upgrade rewards, revenue ticket samples that cover all different regions and distance groups should be used to compare with flight award charts.

Table 3

Simplified U.S. Domestic Flight Award Chart, United MileagePlus (United Airlines, 2019c)

\begin{tabular}{llll}
\hline Cabin Class & Type & Trip Distance & Required Miles \\
\hline \multirow{2}{*}{ Economy } & One-way Saver Award & 700 miles or less & 10,000 \\
Class & One-way Saver Award & & 12,500 \\
& One-way Everyday Award & 32,500 \\
\hline Domestic & One-way Saver Award & 25,000 \\
First Class & One-way Everyday Award & 50,000 \\
\hline
\end{tabular}

\section{Award Availability}

Award availability is a critical factor that has to be considered when assessing the value of frequent flyer miles. Assessed miles values can only be achieved when such awards are available for redemption. Flight or upgrade award availability varies, depending on cabin classes, routes, seasons, and operating carriers. There are two approaches to compare award availabilities of different frequent flyer program. One approach is to let members speak for themselves. Members' votes could measure how satisfied they are in terms of availability of award tickets. The other way is to conduct a systematic sampling of different cabin classes, dates and routes to assess the award availabilities of different programs.

\section{Award Price Index (API)}

Miles of modern frequent flyer programs can be used to redeem for a diverse range of awards. While the purchasing power of frequent flyer miles for different awards could be calculated separately, a single measure is still preferred to an array of measures to represent the overall miles value of a particular program. A single measure could also facilitate the comparison of different frequent flyer programs and simplify the tracking of value change over time.

In order to find such a measure, the construction of Consumer Price Index (CPI) would be used. CPI is a complex measure that is built to record the average price change of goods and services in an economy (Bureau of Labor Statistics, 2019b). The construction of CPI requires stratified sampling and accurate household expenditure data (Bureau of Labor Statistics, 2019a). The U.S. Bureau of Labor Statistics publishes three main CPI series every month, CPI for All Urban 
Consumers (CPI-U), CPI for Urban Wage Earners and Clerical Workers (CPI-W), and Chained CPI for ALL Urban Consumers (C-CPI-U), to represent two target populations. Considering members of most major frequent flyer programs are not all residing in the same country as where the airlines is registered, separate APIs become necessary to represent domestic members of a frequent flyer program and overseas members of the program.

\section{Conversion Rates Between Different Frequent Flyer Programs}

Airlines are essentially a network business, requiring a network of decent coverage to produce economy of scale and to deliver profitability (Bruce, Gao, \& King, 2018). However, due to the technical, economic and regulatory restrictions, no airlines could have an independent global network with unlimited coverage. Airlines, therefore, collaborate with each other to enhance their coverages. The different approaches of airline collaboration include interline agreement, codeshare flights, alliance or joint venture (Bruce et al., 2018).

Flight awards of major network airlines are usually reciprocally redeemable to members of partner airlines, i.e., airlines within the same alliance. However, due to the difference in operational cost, external business environment and taxation rules, the redemption standards for the same flight award could vary significantly between different frequent flyer programs. For instance, to redeem for a short-haul U.S. domestic return trip (one-way distance $<700$ miles) in the economy class on flights operated by United Airlines, a United MileagePlus member would use 20,000 miles if it is a "Saver Award," or 65,000 miles if it is a "Everyday Award." For the same trip, a member of Singapore Airlines' KrisFlyer program will need to use 25,000 miles, if that award seat is made available to partner airlines by United Airlines.

To denote the difference in purchasing power between two currencies when they are used to pay for the same goods or services, the concept of Purchasing Power Parity (PPP) has been developed (Lucio \& Mark, 2002). PPP is based the Law of One Price (LOP or LOOP), which indicates that the same good would be priced the same in different locations when using a common currency (Wallace, 2013). LOP is based on the assumption of frictionless arbitrage, which is extremely rare in real world due to the existence of tariffs, logistics costs and other trading barriers (Lucio \& Mark, 2002). Similarly, in the case of frequent flyer programs, award exclusivity, extra redemption fees and surcharges, and technical barriers need to be taken into consideration when calculating conversion rates between different programs.

\section{Case Study: AAdvantage of American Airlines}

This study uses AAdvantage, the frequent flyer program of American Airlines, as a case study to implement the miles evaluation conceptual model. As the first modern frequent flyer program in the world, AAdvantage was estimated to 
have approximately 100 million members as of 2014 (Leff, 2014). Being a member airline of the Oneworld alliance, American Airlines allows its members to redeem miles for flights awards operated by American Airlines or by their partners airlines, travel awards, and general merchandise awards.

\section{Flight Awards}

American Airlines provides on their website detailed but complicated award charts for flights originating from different regions and of different cabin classes. For demonstration purposes only, this study will only include award flights that are entirely within contiguous 48 U.S. states and Canada. Refer to Table 4 for miles required for different award types within this region.

Table 4

AAdvantage Award Chart for Domestic Flights, in Miles (American Airlines, 2019b)

\begin{tabular}{llll}
\hline & MileSAAver & $\begin{array}{l}\text { AAnytime } \\
\text { Level 1 }\end{array}$ & AAnytime Level \\
& & 40,000 & 60,000 \\
\hline Main Cabin (Economy) & 25,000 & 90,000 & 110,000 \\
Business/First & 50,000 & &
\end{tabular}

Note. 1). The above chart is only for flights that are entirely within contiguous 48 U.S. states and Canada; 2). Miles quoted are for round-trip flights.

As seen in Table 4, AAdvantage of American Airlines charges different number of miles for award flights in different cabin classes. For the same cabin class, either economy or business/first, there are three different types of awards, representing different award availabilities. MilesAAver requires the least number of miles, which is 25,000 miles for a domestic round trip in the economy class. However, the availability of this award is usually extremely limited. AAdvantage members need to book well in advance to be able to access this award type. By comparison, AAnytime Level 2 requires significantly more miles, even travelers still fly in the same economy class as MileSAAver award tickets holders. The availability of this award type is usually much better, similar to the availability of full-fare economy revenue tickets.

To calculate the value of miles when they are used to redeem for different awards listed in Table 4, actual airfares paid by travelers to fly American Airlines are used as references. In the U.S., certified air carriers are required to submit $10 \%$ of ticketing information every month through the Origin and Destination Survey (DB1B) (Bureau of Transportation Statistics, 2019), which will be used as the source of information for airfares by this study. Due to the structure of dataset, it is technically challenging to separate one-way itineraries that meet the award ticket requirements from all the available itineraries. Therefore, this study will use roundtrip itineraries for the purposes of miles valuation. 
The data used are from the third quarter of 2018, the latest reporting period that is available at the time of data collection of this study. In order to improve the quality of data, all the airfares used are from credible sources only, which can be filtered by the Dollar Credibility Indicator variable in the dataset. Airlines are also reporting various ultra-low-fare tickets, including staff benefit tickets that are not available to the public. A close examination of the data finds that such fares are mostly clustered around $\$ 5.50$ and $\$ 11.00$ per ticket area. Therefore, a minimum airfare of $\$ 20$ is used to filter out these non-public tickets, which account for less $1 \%$ of the available ticketing information. Refer to Table 5 and Figure 2 for airfares details of round-trip itineraries of flights operated by American Airlines in Q3, 2018 (Bureau of Transportation Statistics, 2019). The sample size for the economy class airfare is 319,069 , and for business is 28,382 .

Table 5

Percentiles AA Airfares (2018, Q3, Domestic round Trip)

\begin{tabular}{|c|c|c|c|c|c|c|c|c|}
\hline & \multirow{2}{*}{ Mean } & \multicolumn{7}{|c|}{ Percentiles } \\
\hline & & $5 \%$ & $10 \%$ & $25 \%$ & Median & $75 \%$ & $90 \%$ & $95 \%$ \\
\hline \multirow{2}{*}{ Economy } & $\$ 544.8$ & $\$ 23$ & $\$ 27$ & $\$ 36$ & \multirow{2}{*}{$\$ 474$} & \multirow{2}{*}{$\$ 645$} & \multirow{2}{*}{$\$ 877$} & $\$ 107$ \\
\hline & 5 & 6 & 8 & 0 & & & & 9 \\
\hline Business/Firs & $\$ 954.7$ & $\$ 40$ & $\$ 48$ & $\$ 62$ & $\$ 857$ & $\$ 116$ & $\$ 149$ & $\$ 182$ \\
\hline $\mathrm{t}$ & 6 & 3 & 1 & 8 & $\$ 857$ & 4 & 5 & 4 \\
\hline
\end{tabular}




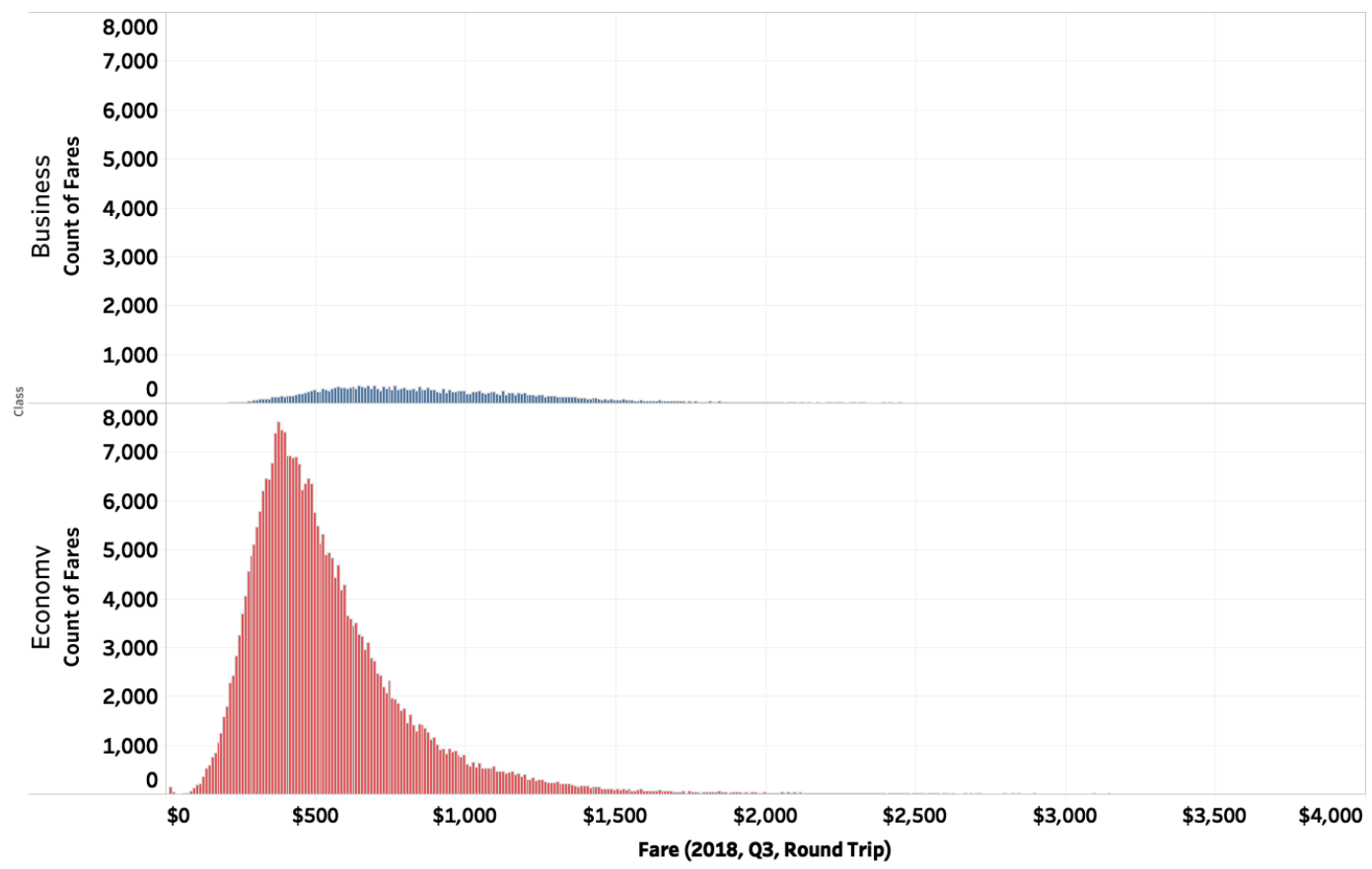

Figure 2. Histograms of AA airfares (2018, Q3, Domestic round Trip).

Using $10 \%$ and $90 \%$ percentiles as the range to cover airfares that $80 \%$ of the travelers would expect to pay had they paid with cash, the equivalent cash value of award tickets can be calculated for different award types. For round-trip itineraries in the economy class, this price range would be $\$ 278-\$ 877$. And for the business class, it would be $\$ 481$ - $\$ 1495$ (See Table 5). Divided by the number of miles required for different award types, the purchasing power of miles could be derived. Refer to Table 6 for values of miles of for different award types. It can be seen the value of AAdvantage miles range between $\$ 0.005$ and $\$ 0.022$ per mile, dependent on specific award types. 
Table 6

Value of AAdvantage Miles When Redeeming for Different Award Types

\begin{tabular}{llll|lll}
\hline \multicolumn{5}{c}{ Main Cabin (Economy) } & \multicolumn{2}{l}{ Business/First } \\
\cline { 2 - 7 } & $\begin{array}{l}\text { MileSAAv } \\
\text { er }\end{array}$ & $\begin{array}{l}\text { AAnytim } \\
\text { e Level 1 }\end{array}$ & $\begin{array}{l}\text { AAnyti } \\
\text { me } \\
\text { Level 2 }\end{array}$ & $\begin{array}{l}\text { MileSAA } \\
\text { ver }\end{array}$ & $\begin{array}{l}\text { AAnytim } \\
\text { e Level 1 }\end{array}$ & $\begin{array}{l}\text { AAnyti } \\
\text { me } \\
\text { Level 2 }\end{array}$ \\
\hline $10 \%$ & $\$ 0.011$ & $\$ 0.007$ & $\$ 0.005$ & $\$ 0.010$ & $\$ 0.005$ & $\$ 0.004$ \\
$90 \%$ & $\$ 0.035$ & $\$ 0.022$ & $\$ 0.015$ & $\$ 0.030$ & $\$ 0.017$ & $\$ 0.014$ \\
Mean & $\$ 0.022$ & $\$ 0.014$ & $\$ 0.009$ & $\$ 0.019$ & $\$ 0.011$ & $\$ 0.009$ \\
\hline
\end{tabular}

It is worth noting that in the valuation of flight awards, taxes and fees that are charged by airlines for award booking are not included. Even U.S. carriers in general do not charge exorbitant fees for domestic flight awards, the inclusion of such charges could lower the value of miles to some extent.

Travel Awards

Miles of major frequent flyer programs can now be used to redeem for a variety of travel awards, including hotel nights, car rentals, and cruise vacations. Three different destinations are chosen here to sample the value of AAdvantage miles for hotel awards redemption. From the results of Table 7, it is quite clearly that American Airlines is using a very stable rate to price hotel awards. This rate oscillates within a very narrow band between $\$ 0.0043$ and $\$ 0.0049$ per mile. 
Table 7

Value of AAdvantage Miles When Redeeming for Hotels (Sampling Date: March 28, 2019)

\begin{tabular}{|c|c|c|c|c|}
\hline $\begin{array}{l}\text { Location \& } \\
\text { Date }\end{array}$ & Hotel & $\begin{array}{l}\text { AAdvantage } \\
\text { (Miles) }\end{array}$ & $\begin{array}{l}\text { American } \\
\text { Express } \\
\text { Travel (Cash } \\
\text { Price) }\end{array}$ & $\begin{array}{l}\text { Rate } \\
\text { (USD/mile) }\end{array}$ \\
\hline \multirow{3}{*}{$\begin{array}{l}\text { New York } \\
\text { (May 8-9, } \\
2019 \text { ) } \\
\text { (1 night, } 2 \\
\text { adults) }\end{array}$} & $\begin{array}{l}\text { Baccarat Hotel \& } \\
\text { Residences } \\
\text { Hilton New York }\end{array}$ & 293,400 & $\$ 1,295.00$ & $\$ 0.0044$ \\
\hline & $\begin{array}{l}\text { Midtown } \\
\text { Hilton New York JFK }\end{array}$ & 73,300 & $\$ 340.00$ & $\$ 0.0046$ \\
\hline & Airport & 61,000 & $\$ 299.00$ & $\$ 0.0049$ \\
\hline \multirow{3}{*}{$\begin{array}{l}\text { Amsterdam } \\
\text { (Oct 16-17, } \\
\text { 2019) } \\
\text { (1 night, } 2 \\
\text { adults) }\end{array}$} & $\begin{array}{l}\text { Sofitel Legend Grand } \\
\text { AMS }\end{array}$ & 78,700 & $\$ 348.00$ & $\$ 0.0044$ \\
\hline & Best Western Plus AMS & 17,400 & $\$ 78.00$ & $\$ 0.0045$ \\
\hline & Hotel Notting Hill & 35,400 & $\$ 174.00$ & $\$ 0.0049$ \\
\hline \multirow{5}{*}{$\begin{array}{l}\text { Shanghai } \\
\text { (Jan 1-2, 2020) } \\
\text { (1 night, } 2 \\
\text { adults) }\end{array}$} & Jumeirah Himalayas & & & \\
\hline & $\begin{array}{l}\text { Hotel } \\
\text { Sofitel Shanghai }\end{array}$ & 37,300 & $\$ 165.00$ & $\$ 0.0044$ \\
\hline & Hongqiao & 41,800 & $\$ 189.00$ & $\$ 0.0045$ \\
\hline & The Ritz-Carlton & & & \\
\hline & Shanghai & 71,500 & $\$ 309.00$ & $\$ 0.0043$ \\
\hline
\end{tabular}

Of note, the value of miles varies dramatically for car rental redemptions. When airfares and hotel rates are transparent and consistent across different sales channels in recent years, the car rental industry still operates differently. Depending on the sales channel and credentials of customers, same products offered by the same company could be priced quite differently. In Table 8, the referencing cash car-rental price was quoted from Booking.com on March 30, 2019. Through conversion, the value of miles for car rentals is between $\$ 0.0028$ and 0.01 per mile. 
Table 8

Value of AAdvantage Miles for Car Rentals (Sampling Date: March 30, 2019)

\begin{tabular}{lllll}
\hline Location \& Date & Company, Model & $\begin{array}{l}\text { AAdvantage } \\
\text { (Miles) }\end{array}$ & $\begin{array}{l}\text { Booking.com } \\
\text { (Cash Price) }\end{array}$ & $\begin{array}{l}\text { Rate } \\
\text { (USD/mile) }\end{array}$ \\
\hline $\begin{array}{l}\text { Orlando, FL, } \\
\text { May 13-17, }\end{array}$ & Budget, Compact & 22,500 & $\$ 206.00$ & $\$ 0.0092$ \\
2019 & Budget, Intermediate & 22,800 & $\$ 218.00$ & $\$ 0.0096$ \\
\hline Los Angeles, & Hertz, Compact & 29,100 & $\$ 75.00$ & $\$ 0.0026$ \\
CA, & Hertz, Intermediate & 33,800 & $\$ 82.00$ & $\$ 0.0024$ \\
Sep 20-23, 2019 & Hertz, Standard & 34,700 & $\$ 121.00$ & $\$ 0.0035$ \\
\hline \multirow{2}{*}{$\begin{array}{l}\text { Jallas, TX, } \\
\text { Jan 1-4, 2020 }\end{array}$} & Dollar, Compact & 46,800 & $\$ 132.48$ & $\$ 0.0028$ \\
& Dollar, Intermediate & 47,900 & $\$ 135.71$ & $\$ 0.0028$ \\
\hline
\end{tabular}

\section{General Merchandise Awards}

Another popular redemption option is general merchandise, which includes goods, gift cards, membership fees, and etc. Due the relatively lower starting price, this option is popular among members who do not have a higher mile balance. Airlines normally work with certain online retailers in order to provide a greater coverage of award categories without running an E-commerce business themselves. This study has sampled a few general merchandise options in order to assess the value of AAdvantage miles. As seen in Table 9, the value of miles can be as low as $\$ 0.004$ per mile if they are used for gift cards redemption, and can also be as high as $\$ 0.024$ per mile due to a special promotion with an identity protection provider.

Table 9

Value of AAdvantage Miles for General Merchandise (Sampling Date: April 1, 2019)

\begin{tabular}{llll}
\hline Merchandise & $\begin{array}{l}\text { AAdvantage } \\
\text { Miles }\end{array}$ & Cash Price & $\begin{array}{l}\text { Rate } \\
\text { (USD/mile) }\end{array}$ \\
\hline $\begin{array}{l}\text { AA Admiral Club Membership - } \\
\text { New, individual, regular member }\end{array}$ & 65,000 & $\$ 650.00$ & $\$ 0.010$ \\
$\begin{array}{l}\text { Gift Cards -BP, Home Depot, \& etc. } \\
\begin{array}{l}\text { LifeLock Standard } \\
\text { protection }(6-m o n t h)\end{array}\end{array}$ & 6,412 & $\$ 25.00$ & $\$ 0.004$ \\
\hline
\end{tabular}

\section{Flight Awards Availability}

To evaluate the availability of flight awards, this study conducts a limited sampling on six different routes, including three domestic and three international 
routes. Four departure dates are used, representing booking award tickets 7, 30, 90 and 300 days in advance, with the sampling date being April 7, 2019. The durations of sampled trips are three days, a week and two weeks respectively. See Table 10 for availabilities of sampled routes/dates.

Table 10

AAdvantage Award Availabilities (Sampling date: April 7, 2019)

\begin{tabular}{|c|c|c|c|c|c|c|c|c|}
\hline & \multicolumn{2}{|c|}{ 7-day in advance } & \multicolumn{2}{|c|}{ 30-day in advance } & \multicolumn{2}{|c|}{ 90-day in advance } & \multicolumn{2}{|c|}{ 300-day in advance } \\
\hline & Outbound & Inbound & Outbound & Inbound & Outbound & Inbound & Outbound & Inbound \\
\hline & 13-Apr & 16-Apr & 6-May & 13-May & 6-Jul & 13-Jul & $6-\mathrm{Feb}$ & 20-Feb \\
\hline DFW-NYC & $T Y U J \& F$ & TYUJ $\not$ र & $T Y U J \& F$ & 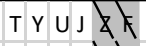 & $T Y U J \& F$ & 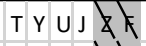 & TY ४ \& $\bar{k}$ & $T Y \cup J$ \\
\hline IND-SEA & 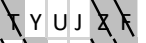 & T Y u $\not \Varangle \bar{k}$ & T y u $又 \bar{k}$ & TYus $\not k$ & trus $\bar{k} k$ & TY U । $\Varangle k$ & T Y U ব $\not k$ & $T Y \cup J$ \\
\hline ATL-DEN & $x \times \cup, \frac{x}{x}$ & TYus $\not k$ & TYus $\frac{k}{k}$ & TYus $\Varangle k$ & 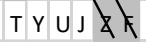 & TYus $\not k$ & TYus $\Varangle k$ & TY Y J \\
\hline NYC-LHR & $T Y \cup J \not F$ & $T Y U J Z F$ & $T Y \cup J \Varangle F$ & T Y U J Z F & $T Y U J Z F$ & $Y \cup J Z F$ & $T Y \cup J Z F$ & $T Y \cup J Z$ \\
\hline LAX-SYD & $T Y \cup \in \not k$ & $x y<j \neq=$ & 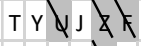 & Ty $\alpha, \not k$ & & & Tr $<J \& k$ & \\
\hline DFW-GRU & 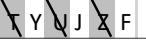 & $x y \& J F$ & $T Y \cup J \notin F$ & $T Y \& J \notin F$ & & $J \& F$ & $T Y \& J \& F$ & \\
\hline
\end{tabular}

Note. Letters in the table represent award availability of different fare classes. Greyed and crossed out cells indicate awards are unavailable. T: Economy MileSAAver; Y: Economy AAnytime; U: Business/First MileSAAver; J: Business/First AAnytime; Z: First MileSAAver; F:

First AAnytime

As seen from this limited sample, AAdvantage of American Airlines offers good award availabilities on domestic routes. Economy and Business MileSAAver awards are available for redemption on most of the days in all three markets. However, on the international routes, in particular for flights to Sydney, Australia and Sao Paulo, Brazil, Business MileSAAver awards are mostly not available, which means AAdvantage members who wish to redeem their miles for business class tickets would have to spend more miles for the AAnytime awards.

There could be system limitations in providing award tickets on flights operated by partner airlines. Recently, Schlappig (2019) of One Mile at A Time, an online blog focusing on travel, lifestyle and rewards, report that United Airlines is not showing any award tickets of Singapore Airlines, TAP Air Portugal, and Thai Airways as of January, 2019, even these airlines are Star Alliance member airlines. Limitations as such would negatively affect the value of miles of a program.

\section{Exchange Rate Between Programs}

Two other Oneworld alliance programs, Executive Club of British Airways and Frequent Flyer of Qantas Airways, are selected to compare against AAdvantage of American Airlines. The redemption standard of AAdvantage is mostly regionbased. For example, traveling within the continuous 48 U.S. states and Canada would require 12,500 miles one-way if MilesSAAver award tickets are available for redemption, regardless of the actual flying distance. By comparison, British 
Airways and Qantas Airways price award flights according to the distance between origin and destination (See Tables 11 and 12).

By calculating the number of miles required for Executive Club of British Airways and Frequent Flyer of Qantas Airways to redeem for the same award tickets, exchange rates between different frequent flyer programs can be calculated. This study uses two sample routes, Indianapolis to Chicago (177 miles) and Seattle to San Juan, Puerto Rico (3,729 miles). Refer to Table 13 for the number of AAdvantage miles required for different types of awards. Analysis results reveal that the value of one Qantas Frequent Flyer point varies from 0.42 to 4.96 AAdvantage mile, and the ratio from British Airway's Avios (BA's term for miles) to AAdvantage is 0.3 to 4 . Refer to Table 14 for details.

Table 11

Qantas Classic Flight Reward Table (worldwide) (As of April, 2019; Qantas, 2019b)

\begin{tabular}{llllll}
\hline & & \multicolumn{5}{c}{ Premium } \\
Zone & One-Way Miles & Economy & Economy & Business+ & First \\
\hline 1 & $0-600$ & 8,000 & 12,000 & 16,000 & 24,000 \\
2 & $601-1,200$ & 12,000 & 18,000 & 24,000 & 36,000 \\
3 & $1,201-2,400$ & 18,000 & 27,000 & 36,000 & 54,000 \\
4 & $2,401-3,600$ & 22,500 & 37,000 & 50,000 & 75,000 \\
5 & $3,601-4,800$ & 28,000 & 45,000 & 60,000 & 90,000 \\
6 & $4,801-5,800$ & 35,000 & 54,000 & 72,000 & 108,000 \\
7 & $5,801-7,000$ & 40,000 & 63,000 & 84,000 & 126,000 \\
8 & $7,001-8,400$ & 45,000 & 72,000 & 96,000 & 144,000 \\
9 & $8,401-9,600$ & 55,000 & 84,000 & 112,000 & 168,000 \\
10 & $9,601-15,000$ & 60,000 & 96,000 & 128,000 & 192,000 \\
\hline
\end{tabular}


Table 12

British Airways Avios award Chart (As of April, 2019; Steinberg, 2018)

\begin{tabular}{|c|c|c|c|c|c|c|c|c|}
\hline \multirow[b]{2}{*}{$\begin{array}{l}\text { Distance } \\
\text { (miles) }\end{array}$} & \multicolumn{6}{|c|}{ Premium } & \multicolumn{2}{|l|}{ First } \\
\hline & $\begin{array}{l}\text { Off } \\
\text { Peak }\end{array}$ & Peak & $\begin{array}{l}\text { Off } \\
\text { Peak }\end{array}$ & Peak & $\begin{array}{l}\text { Off } \\
\text { Peak }\end{array}$ & Peak & $\begin{array}{l}\text { Off } \\
\text { Peak }\end{array}$ & Peak \\
\hline $\begin{array}{l}1-650 * \\
651\end{array}$ & 4,000 & 4,500 & 5,750 & 6,750 & 7,750 & 9,000 & 15,500 & 18,000 \\
\hline $\begin{array}{l}1150 \\
1151-\end{array}$ & 6,500 & 7,500 & 9,500 & 11,250 & 12,750 & 15,000 & 25,500 & 30,000 \\
\hline $\begin{array}{l}2000 \\
2001-\end{array}$ & 8,500 & 10,000 & 12,750 & 15,000 & 17,000 & 20,000 & 34,000 & 40,000 \\
\hline $\begin{array}{l}3000 \\
3001-\end{array}$ & 10,000 & 12,500 & 20,000 & 25,000 & 31,250 & 37,500 & 42,500 & 50,000 \\
\hline $\begin{array}{l}4000 \\
4001-\end{array}$ & 13,000 & 20,000 & 26,000 & 40,000 & 50,000 & 60,000 & 68,000 & 80,000 \\
\hline $\begin{array}{l}5500 \\
5501-\end{array}$ & 16,250 & 25,000 & 32,500 & 50,000 & 62,500 & 75,000 & 85,000 & 100,000 \\
\hline $\begin{array}{l}6500 \\
6501-\end{array}$ & 19,500 & 30,000 & 39,000 & 60,000 & 75,000 & 90,000 & 102,000 & 120,000 \\
\hline 7000 & 22,750 & 35,000 & 45,500 & 70,000 & 87,500 & 105,000 & 119,000 & 140,000 \\
\hline $7001+$ & 32,500 & 50,000 & 65,000 & 100,000 & 125,000 & 150,000 & 170,000 & 200,000 \\
\hline
\end{tabular}


Table 13

Sample Routes for AAdvantage Miles Pricing (As of April, 2019)

\begin{tabular}{llllll}
\hline $\begin{array}{l}\text { Route } \\
\text { Type }\end{array}$ & & $\begin{array}{l}\text { Economy } \\
\text { MileSAAver }\end{array}$ & $\begin{array}{l}\text { Economy } \\
\text { AAnytime }\end{array}$ & $\begin{array}{l}\text { Business } \\
\text { MileSAAver }\end{array}$ & $\begin{array}{l}\text { Business } \\
\text { AAnytime }\end{array}$ \\
\hline Short & $\begin{array}{l}\text { IND-ORD } \\
(177 \text { Miles })\end{array}$ & $7.5 \mathrm{~K}$ & $20 \mathrm{~K}-30 \mathrm{~K}$ & $15 \mathrm{~K}$ & $45 \mathrm{~K}-75 \mathrm{~K}$ \\
Long & $\begin{array}{l}\text { SEA-SJU } \\
(3,729\end{array}$ & $\begin{array}{l}12.5 \mathrm{~K}- \\
17.5 \mathrm{~K}\end{array}$ & $\begin{array}{l}27.5 \mathrm{~K}- \\
65 \mathrm{~K}\end{array}$ & $25 \mathrm{~K}$ & $50 \mathrm{~K}-90 \mathrm{~K}$ \\
& & & & \\
\hline
\end{tabular}

Table 14

Exchange Rates of Other Programs to AAdvantage (in 1 AAdvantage mile)

\begin{tabular}{llllll}
\hline \multirow{2}{*}{ in AA miles } & $\begin{array}{l}\text { Economy } \\
\text { MileSAAver }\end{array}$ & $\begin{array}{l}\text { Economy } \\
\text { AAnytime }\end{array}$ & $\begin{array}{l}\text { Business } \\
\text { MileSAAver }\end{array}$ & $\begin{array}{l}\text { Business } \\
\text { AAnytime }\end{array}$ & $\begin{array}{l}\text { Summary } \\
\text { Range }\end{array}$ \\
\hline QF - AA (Short) & 0.95 & $2.50-3.75$ & 0.94 & $2.81-4.69$ & $0.94-4.69$ \\
QF - AA (Long) & $0.45-0.63$ & $0.98-2.32$ & 0.42 & $0.83-1.50$ & $0.42-2.32$ \\
BA - AA (Short) & $1.00-1.15$ & $2.67-4.00$ & 0.30 & $0.75-1.25$ & $0.30-4.00$ \\
BA - AA (Long) & $0.63-1.35$ & $1.38-3.25$ & 0.50 & $0.83-1.50$ & $0.50-3.25$ \\
\hline \multicolumn{7}{c}{ Note. BA-British Airways; QF- Qantas Airways; AA-American Airlines }
\end{tabular}

\section{Rates of Purchasing Miles}

Airlines are selling miles directly to their members, and some airlines offer frequent discounts or bonus miles to drive up sales. For instance, in April, 2019, AAdvantage of American Airlines runs a promotion that offers bonus miles for miles purchases made before April 30, 2019. This study has calculated the unit selling price and has taken into consideration $7.5 \%$ U.S. federal exercise tax for miles purchase. As seen in Figure 3, the unit cost is variable due to the variable bonus miles for purchases of different amounts. The rate starts at $\$ 0.051$ per mile if only buying 2,000 miles, the lowest allowable purchase amount. That cost quickly drops to as low as $\$ 0.019$ if buying 150,000 miles, the maximum allowed amount in a calendar year, and receiving 100,000 bonus miles. Because of the way how bonus miles are calculated, the total number of miles received have several "gaps" in Figure 3. 


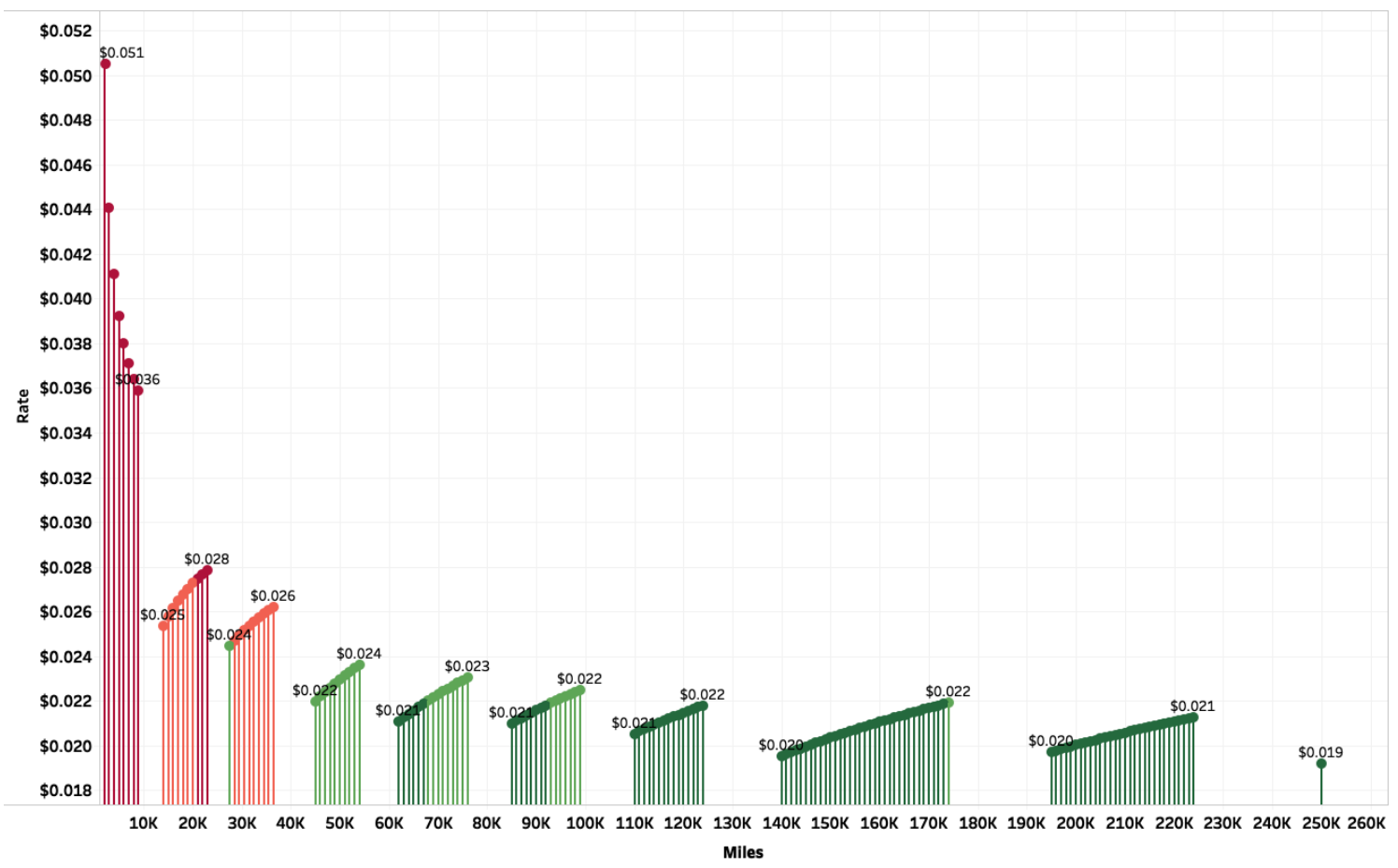

Figure 3. The unit cost of buy AAdvantage miles (April, 2019; American Airlines, 2019a).

Another debatable topic in valuing frequent flyer program miles is using revenue tickets as pricing reference. Intuitively, revenue tickets of flights operated by hosting airline of the frequently flyer program should be chosen as references, which is the practice of this study and those in literature. However, one can argue that the fundamental product delivered by the airline industry is to transport passengers or cargo from origin to destination regardless of the operating carrier. At least for budget sensitive travelers, they are more likely to select airlines based on airfare instead of other factors. For these travelers, the reference cash price for miles valuation should be tickets of the lowest airfare, instead of the hosting airline by fault. However, such an approach will bring in new challenges of matching terms and conditions of different airlines and flexibility of different tickets. The reference ticket issue needs to be discussed and studied in future studies.

\section{Discussion}

Airlines are facing the challenge created by the success of their own frequent flyer programs. On one hand, the profit driven nature of business is pushing airlines to continuously expand and to grow their frequent flyers base. On the other hand, airlines are restricted by their own fleet capacity in providing 
adequate supply of flight awards at a stable redemption rate. Devaluing miles is then an inevitable solution to this challenge but it is by no means a preferred approach, as frequent devaluation drives even the most loyal members away to competing programs. The latest strategy adopted by the airline industry is to stop publishing award charts. Instead, airlines such as Delta started to introduce "dynamic pricing" to flight awards since 2016 (Live and Let's Fly, 2015). Airlines will determine, at the time of redemption, the rate of flight awards depends on the market and sales. This practice is soon to be followed by United Airlines in 2019 (United Airlines, 2019a). When travelers are gradually losing their access to previously available award charts, studies such as this one become critical in providing valuable information for travelers to accurately assess the value of their miles assets.

In addition to valuation, the ease of redemption and award availably are two other critical factors that could have a profound impact on the utility of frequent flyer miles but are generally dismissed by travelers during the accumulation of miles. Travel bloggers discuss these issues occasionally but rarely provide an objective assessment, in large due to the technical challenge of sampling multiple routes and dates. This study specifically highlights both issues, and suggests a direction for future assessments. Travelers are recommended to evaluate these two factors when deciding which program suits their needs better.

An issue that has been consistently dismissed by previous studies addressing redemption values of frequent flyer miles is the minimum miles required for certain rewards. For cash, even the smallest denomination could be used to settle debts or to purchase goods, in theory. But when using frequent flyer miles, award redemption starts with a certain number of miles, which makes frequent flyer accounts with only limited miles barely usable. For instance, the MileagePlus program of United Airlines requires at least 10,000 miles for a one-way domestic saver award flight (United Airlines, 2019c), and the Executive Club of British Airways needs a minimum of 4,000 Avios for a one-way off-peak flight with a total flight distance no more than 650 miles (British Airways, 2019). This minimum miles requirement must be taken into consideration when value the purchasing power of frequent flyer miles.

Airlines are pushing their frequent flyers to online or mobile booking by charging extra service fee if award tickets are booked through phone service or over the counter. For instance, American Airlines charges \$30 per ticket for domestic travel and $\$ 40$ for international travel if award tickets are issued by reservation agents (American Airlines, 2019c). However, websites of several major airlines are limited in their capabilities of displaying award tickets on flights operated by partner airlines. For instance, American Airlines won't display award flights operated by Cathay Pacific Airways, even seats are available for redemption. AAdvantage members would have to call reservations to book. Similarly, most Star 
Alliance member airlines do not display award flights operated by Singapore Airlines on their websites. Such a limitation would possibly prevent some members from realizing the best possible value of their miles if they are not aware of such limitations.

Collaboration is essential for the airline industry, and loyalty programs of most major airlines allow their members to redeem award flights operated by partner carriers. However, they generally do not allow members to trade their miles with other frequent flyer programs, mostly due to the potential business implications on their own revenue management. For example, United Airlines specifically raises "prohibition of sale or barter" in their Rules for the MilleagePlus program (United Airlines, 2019d). The only exception to such prohibitions in the airline industry is between Singapore Airlines and Virgin Australia. Both airlines allow members to transfer point balance to the other airline at the rate of 1.55 to 1 (Singapore Airlines, 2019). This conversion rate does not necessarily represent the relative value of two programs, as it applies to transfers in both directions. Instead, the rate includes a hefty penalty component of $35 \%$ for every mile transferred out of either program. Nevertheless, the comparison of relative value across different frequent flyer programs is necessary and meaningful as it provides consumers a guide for choice.

As one of groundbreaking scholarly studies in valuing frequent flyer miles, this study has its limitations. The assessment of domestic flight award value is based on the actual booking data from the third quarter of 2018. It is very likely the distribution of airline's yield may vary in other seasons, therefore resulting in slightly different results in miles valuation. The value of flight awards and award availability are separately assessed in this study, which means award tickets of certain values, especially the more restrictive award types, may not always be available for redemption. It is also impossible to construct an Award Price Index at the moment due to missing information on miles expenditure. Therefore, a single rate that represents the overall miles value of a frequent flyer program can only be supplied in future studies.

\section{Conclusions}

As frequent flyer programs have developed diverse ways of earning and redeeming miles, valuing miles has become a complex task. The purchasing power of miles depends on categories of awards, and could vary significantly from one category to another. Using AAdvantage of American Airlines for example, its value varies between $\$ 0.0024$ to $\$ 0.035$ per mile (See Figure 4). Across different award types, the least valuable way of using AAdvantage miles is to redeem for rental cars. Flight awards in general offer better returns in value for the same number of miles. Compared with other award types, hotel awards deliver the most consistent 
rate, with the value of miles oscillates within a very narrow band from $\$ 0.0043$ to $\$ 0.0049$ per mile.

For flight awards, award types determine the value of miles. At the moment, American Airlines offers three award types for each cabin class, which are MileSAAver, AAnytime Level 1 and AAnytime Level 2. Different award types charge different number of miles for the same cabin class, and present different award availabilities. MileSAAver in both economy class and business/first class offers the best value for miles redemption, with the mean value sitting at $\$ 0.022$ per mile for economy MileSAAver award and $\$ 0.019$ per mile for business/first MileSAAver award. By comparison, AAnytime awards offer a much lower rate for miles redemption, but they still could be useful for members who prefer better award availabilities.

Buying miles directly from airlines does not seem to be a sensible option for most travelers unless miles are purchased to top up accounts so that there are enough miles for certain awards. This study finds that the actual purchasing power of AAdvantage miles are lower than the average cost of buying miles, even with the current promotion of bonus miles. Unless consumers are buying the highest possible number of miles to achieve the best rate of $\$ 0.019$ per mile and are using these purchased miles for MileSAAver awards, otherwise they should consider pay itineraries with cash instead of buying miles for award flights. In addition, purchasing 250,000 miles inclusive of bonus miles requires an upfront payment of $\$ 4794.50$, which could be formidable for most travelers.

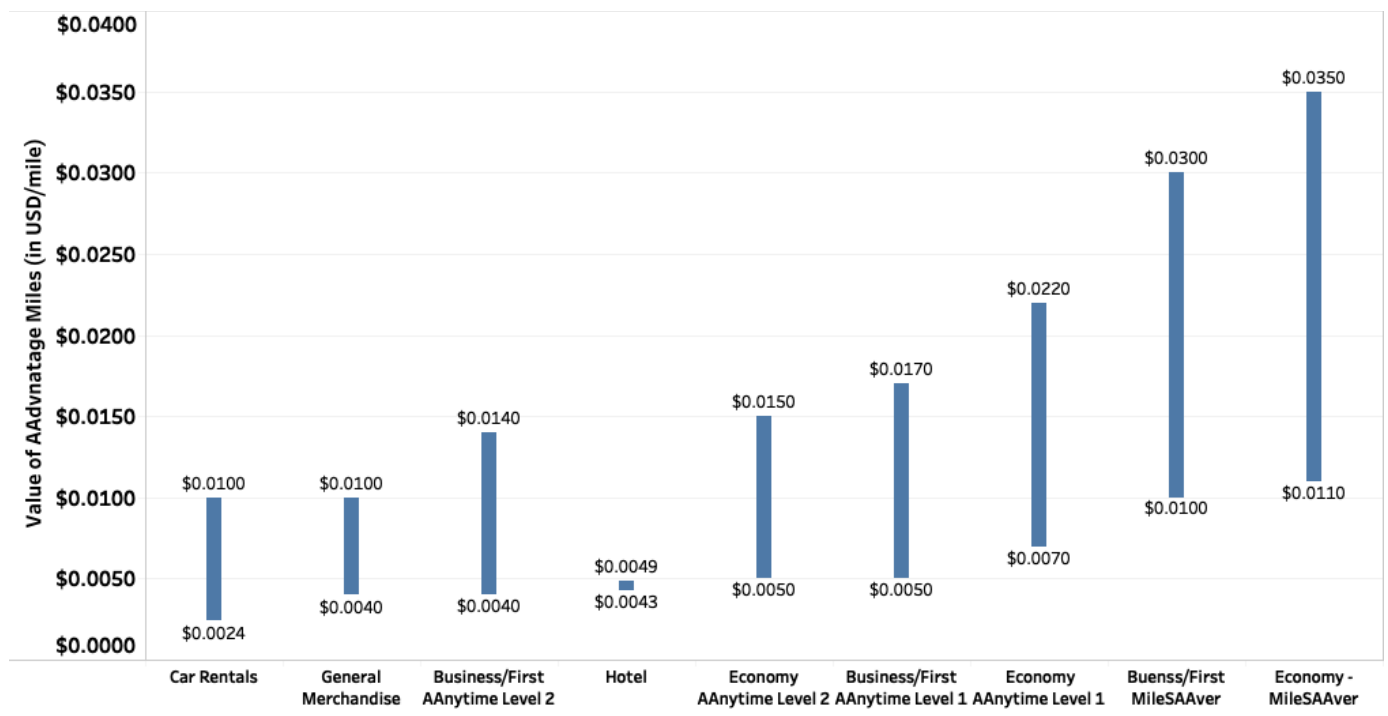

Figure 4. Values of AAdvantage miles by award categories. 
As proven by the current study, the value of frequent flyer program miles is variable, which depends on redemption scenarios and could be further restricted by the number of miles possessed by individual consumers. Therefore, a general guidance to assist the majority of consumers achieve the highest utility when redeeming miles is not possible. Travelers are strongly recommended to follow the valuation process introduced by this study and individual travel needs, preference, and future miles accumulation projection to develop a redemption strategy that better fits their personal objectives.

A fair and up-to-date assessment of the value of frequent flyer program miles has its business implications on multiple perspectives. To consumers, it will allow them to have an accurate estimation of miles assets and to make more informed decisions both in accumulation and in redemption of miles. To airlines, this will provide a different guidance to measure their deferred revenues, in addition to the internal accounting standards, so that better resource allocation decisions could be made. To airline partners, fair valuation of miles will provide a basis for negotiating a more competitive rate when acquiring miles from airlines. And finally, to investors, it is usually perplexing to assess the exact impact of outstanding miles on airlines' balance sheet. Instead of using the rate that airline is selling miles to their partners and customers, rates derived from a rigorous study could provide a more accurate estimation to guide the assessment. 


\section{References}

Aeroplan. (2019). General terms and conditions. Aeroplan Terms and Conditions. Retrieved from https://www.aeroplan.com/terms_and_conditions.do

American Airlines. (2019a). Buy miles \& gift miles. Retrieved from https://buymiles.americanairlines.com/

American Airlines. (2019b). Flight award chart. AAdvantage program. Retrieved from https://www.aa.com/i18n/aadvantage-program/miles/redeem/awardtravel/flight-award-chart.jsp

American Airlines. (2019c). Optional service fees. Retrieved from https://www.aa.com/i18n/customer-service/support/optional-servicefees.jsp\#ticketing

American Airlines. (2019d). Redeem miles. AAdvantage program. Retrieved from https://www.aa.com/i18n/aadvantage-program/miles/redeem/redeemmiles.jsp?anchorEvent $=$ false $\&$ from $=\mathrm{Nav}$

Banoff, S., \& Lipton, R. (2012). Taxing your miles won't bring smiles: What value is reportable? Journal of Taxation, 116(3), 173-176.

Banoff, S., \& Lipton, R. (2014). Tax court taxes frequent flier miles: Timing, valuation issues still up in the air. Journal of Taxation, 121(4), 187-192.

Banoff, S., \& Lipton, R. (2015). Bug bounty brings miles, but taxes bite: What value is reportable? Journal of Taxation, 123(4), 189-192.

Basumallick, D., Ozdaryal, B., \& Madamba-Brown, C. (2013). Perceived value of a mile. Journal of Revenue and Pricing Management, 12(1), 8-15. doi:10.1057/rpm.2012.34

British Airways. (2019). Use your Avios to explore the world. Reward Flights. Retrieved from https://www.britishairways.com/en-us/executiveclub/spending-avios/reward-flights

Bruce, P. J., Gao, Y., \& King, J. M. C. (2018). Airline operations: A practical guide: Abingdon, Oxon ; New York, NY : Routledge.

Bureau of Labor Statistics. (2019a). Consumer expenditure surveys. Retrieved from https://www.bls.gov/cex/

Bureau of Labor Statistics. (2019b). Consumer price index. Economic Releases. Retrieved from https://www.bls.gov/news.release/cpi.toc.htm

Bureau of Labor Statistics. (2019c). CPI home. Retrieved from https://www.bls.gov/cpi/

Bureau of Transportation Statistics. (2019). Airline origin and destination survey $(D B 1 B)$. Retrieved from https://www.transtats.bts.gov/Tables.asp? DB_ID=125\&DB_Name=Airline\%20Origin\%20and\%20Destination\%20 Survey\%20\%28DB1B\%29\&DB_Short_Name=Origin\%20and\%20Destina tion\%20Survey 
Chan, M., Kemp, S., \& Finsterwalder, J. (2016). The concept of near money in loyalty programmes. Journal of Retailing and Consumer Services, 31, 246-255. doi:10.1016/j.jretconser.2016.04.008

Crawford, B. (2013). Reward miles: An important new medium of payment. Banking \& Finance Law Review, 28(2), 213-224.

Creditcards.com. (2018). How much are American Airlines miles worth? Retrieved from https://www.creditcards.com/credit-card-news/americanairlines-miles-value.php

de Boer, E. R., \& Gudmundsson, S. V. (2012). 30 years of frequent flyer programs. Journal of Air Transport Management, 24, 18-24. doi:10.1016/j.jairtraman.2012.05.003

Dennis-Escoffier, S. (1996). IRS backs away from taxing frequent flyer miles. The Journal of Corporate Accounting \& Finance, 7(3), 125.

Gao, Y., Carrigg, M., Lewinski, R., Polderman, D., \& Tkalcevic, P. (2018). The perceived value of frequent flyer program benefits among Australian travelers. International Journal of Aviation, Aeronautics, and Aerospace, 5(3). https://doi.org/10.15394/ijaaa.2018.1249

Jalbert, T., Stewart, J. D., \& Martin, D. (2010). The value of credit card benefits. Financial Services Review, 19(3), 227.

Keh, H. T., \& Lee, Y. H. (2006). Do reward programs build loyalty for services?: The moderating effect of satisfaction on type and timing of rewards. Journal of Retailing, 82(2), 127-136. doi:10.1016/j.jretai.2006.02.004

Leff, G. (2014). How many elite members do frequent flyer programs have? View from the Wing. Retrieved from https://viewfromthewing.boardingarea.com/2014/11/22/many-elitemembers-frequent-flyer-programs/

Liston-Heyes, C. (2002). Pie in the sky? Real versus perceived values of air miles. Journal of Consumer Policy, 25(1), 1-26. doi:10.1023/A:1014594718701

Live and Let's Fly. (2015). Special report: Delta's secret Skymiles devaluation. Boarding Area. Retrieved from https://liveandletsfly.boardingarea.com/ 2015/07/09/special-report-deltas-secret-skymiles-devaluation/

Lucio, S., \& Mark, P. T. (2002). Purchasing power parity and the real exchange rate. IMF Staff Papers, 49(1), 65. doi:10.2307/3872492

Mutzabaugh, B. (2018). Want to visit a 747 boneyard? How many United miles do you have? USA Today. Retrieved from https://www.usatoday.com/ story/travel/flights/todayinthesky/2018/05/16/united-airlines-boeing-747boneyard-auction/615800002/

Nevius, A. M. (2012). Are frequent flyer miles taxable? Journal of Accountancy, 214(2), 75.

One Mile at a Time. (2019). Value of miles \& points. Retrieved from https://onemileatatime.com/value-miles-points/ 
Qantas. (2018). Qantas annual report 2018. Retrieved from https://investor.qantas.com/FormBuilder/_Resource/_module/doLLG5ufY kCyEPjF1tpgyw/file/annual-reports/2018-Annual-Report-ASX.pdf

Qantas. (2019a). Use Qantas points. Qantas points and partners. Retrieved from https://www.qantas.com/fflyer/dyn/qantas-points-partners/using-points

Qantas. (2019b). Using points for rewards. Using Qantas points. Retrieved from https://www.qantas.com/fflyer/dyn/flying/using-points-awardsupgrades\#classic-flight-rewards

Rowell, D. M. (2010, August 25, 2018). A history of us airline deregulation part 4: 1979 - 2010: The effects of deregulation - lower fares, more travel, frequent flier programs. The Travel Insider. Retrieved from https://thetravelinsider.info/airlinemismanagement/airlinederegulation2.ht $\mathrm{m}$

Schlappig, B. (2019). United blocking Singapore, Thai, and TAP Portugal awards. One mile at a time. Retrieved from https://onemileatatime.com/unitedblocking-partner-awards/

Singapore Airlines. (2019). Other ways to redeem miles. PPS Club/KriFlyer. Retrieved from https://www.singaporeair.com/en_UK/es/ppsclubkrisflyer/use-miles/otherways-to-redeem-miles/

Steinberg, E. (2018). Maximizing the British Airways distance-based award chart. The Points Guy. Retrieved from https://thepointsguy.com/guide/ maximizing-british-airways-award-chart/

The Points Guy. (2019). What are points \& miles worth? Retrieved from https://thepointsguy.com/guide/monthly-valuations/

United Airlines. (2019a). Award travel updates. Retrieved from https://www.united.com/ual/en/us/fly/mileageplus/awards/award-travelupdates.html

United Airlines. (2019b). Earn award miles. MileagePlus. Retrieved from https://www.united.com/web/en-US/content/mileageplus/earn/default.aspx

United Airlines. (2019c). Interactive travel destinations award chart. MileagePlus. Retrieved from https://www.united.com/web/enus/apps/mileageplus/awards/travel/awardTravel.aspx?POS=US

United Airlines. (2019d). Rules for the MileagePlus Program. MileagePlus Rules. Retrieved from https://www.united.com/ual/en/us/fly/mileageplus/ rules.html

United Airlines. (2019e). Use award miles. MileagePlus. Retrieved from https://www.united.com/ual/en/us/fly/mileageplus/awards.html

Wallace, F. (2013). Cointegration tests of purchasing power parity. Weltwirtschaftliches Archiv, 149(4), 779-802. doi:10.1007/s10290-0130165-2 